\title{
PENGARUH MODEL PEMBELAJARAN KOOPERATIF TIPE NHT TERHADAP HASIL BELAJAR TEKNIK DASAR PASSING BOLA VOLI
}

\author{
Mayza Pironanda Patah, I Wayan Artanayasa ${ }^{2}$, I Gede Suwiwa ${ }^{3}$ \\ Prodi Pendidikan Jasmani, Kesehatan dan Rekreasi \\ Jurusan Pendidikan Olaraga \\ Fakultas Olahraga dan Kesehatan \\ Universitas Pendidikan Ganesha \\ Kampus Jineng Dalem Undiksha Singaraja, Bali \\ e-mail: christian_patah@ymail.com¹, iwayan.artanayasa@yahoo.com², \\ suwiwagede@gmail.com³
}

\begin{abstract}
ABSTRAK
Penelitian ini bertujuan untuk mengetahui pengaruh model pembelajaran Kooperatif tipe Numbered Head Together (NHT) terhadap hasil belajar teknik dasar passing bola voli. Jenis penelitian adalah eksperimen sungguhan (true experimental) dengan rancangan the randomized pretest-posttest control group the same subjec design. Populasi penelitian ini adalah seluruh siswa kelas XI SMA Saraswati Seririt tahun pelajaran 2019/2020, keseluruhan kelas berjumlah 5 kelas dengan populasi 180 orang. Pengambilan sampel yang digunakan simple random sampling berdasarkan kelas. Kelas yang menjadi sampel penelitian adalah kelas XI IIS 4 sebagai kelompok eksperimen dan XI MIA sebagai kelompok kontrol. Eksperimen dilakukan sebanyak 2 kali perlakuan diluar pretes-posttest. Data hasil belajar dikumpulkan melalui tes objektif, observasi dan unjuk kerja. Analisis data menggunakan uji-t dengan bantuan SPSS 16.0 for Windows. Ratarata kelompok eksperimen adalah 0.70 lebih tinggi dari rata-rata kelompok kontrol adalah 0.62 . Signifikansi pada uji hipotesis diperoleh melalui uji parametrik (uji Independent Samples Test) adalah 0.019 yaitu p<0,05. Disimpulkan bahwa model pembelajaran Kooperatif tipe Numbered Head Together (NHT) berpengaruh signifikan terhadap hasil belajar teknik dasar passing bola voli. Disarankan kepada guru penjasorkes dapat menerapkan model pembelajaran Kooperatif tipe Numbered Head Together (NHT) karena terbukti berpengaruh signifikan terhadap hasil belajar siswa.
\end{abstract}

Kata kunci : $N H T$, hasil belajar, bola voli.

\section{ABSTRACT}

This research aimed to determine the effect of Cooperative Type Numbered Head Together (NHT) learning model to the learning outcomes of basic techniques passing volley ball. This research was a trueexperimental researching the randomized pretest-posttest control group the same subject design. The research population was students of class XI Saraswati Seririt High School academic year 2019/2020, with the 5 classes and population of the research was 180 peoples. Sampling technique used was simple random sampling based on class. The class into the sample was class XI IIS 4 as experimental group and XI MIA as control group. The experimental was conducted two times treatment outside of pretest-posttest. Data were collected through objectif tests, observation and performance tests. Data analysis using t-test with SPSS 16.0 for Windows. Average on experimental group was 0.70 higher than average control was 0.62 . Significance on tests of hypotheses obtained through parametric test (independent Samples Test) was 0.019 it was $p<0,05$. Based on the above exposure, Cooperative Type Numbered Head Together (NHT) learning model effect significantly to the result of learning basic techniques passing volley ball. It is recommended to the penjasorkes teacher can implement (NHT) learning model because proven effect significantly to the improvement of student's learning outcome.

Key words: NHT, learning outcomes, volleyball 


\section{PENDAHULUAN}

Proses pembelajaran merupakan suatu interaksi antara guru dengan siswa yang dimana proses ini memiliki tujuan untuk mencapai tujuan pembelajaran. Namun saat ini masih ada guru yang menganut pemahaman lama, yaitu guru sebagai pusat pembelajaran. Jadi disini guru yang mendominasi proses pembelajaran dan hanya memberikan semua pengetahuannya kepada siswa. Dan sebagai siswa hanya dapat menerima informasi yang diberikan tanpa berusaha mencari sendiri apa yang mereka ingin ketahui. Materi yang disajikan oleh guru menjadi bahan hafalan bagi siswa. Hal ini menyebabkan konsep yang diterima oleh siswa tidak dapat diterima dengan baik.

Peningkatan kualitas pembelajaran sangat dipengaruhi oleh faktor siswa, alat pendukung terjadinya pembelajaran, dan lingkungan. Alat pendukung pembelajaran meliputi guru, kurikulum, sarana dan prasarana. Guru merupakan alat pendukung pembelajaran karena guru bertugas mempersiapkan dan mengelola pembelajaran. Siswa diharapkan dapat berperan penuh dalam proses pembelajaran dengan guru sebagai fasilitator.

Para pakar pendidikan telah banyak mengadakan terobosan tentang model pembelajaran yang telah diujicobakan namun sampai sekarang belum bisa dipastikan mana yang paling tepat, karena dalam proses pembelajaran sangat tergantung pada kondisi dan situasi siswa itu sendiri. Oleh karena itu, salah satu penanggulangan permasalahan dalam pendidikan adalah dengan melakukan penelitian-penelitian guna mencari alternatif pemecahan masalah. Penelitian dapat dilakukan oleh guru atau calon guru guna mencari fakta-fakta pada saat pembelajaran berlangsung, sebagai contoh yaitu mencari data yang akan menunjukan letak permasalahan pada proses pembelajaran. Salah satu langkah yang dilakukan guru agar pembelajaran berjalan efektif dan efisien adalah memahami dan menguasai bahan pelajaran, menerapkan berbagai metode, pendekatan dan strategi pembelajaran sehingga hasil belajar siswa dapat tercapai secara optimal.

Model pembelajaran kooperatif tipe NHT atau penomoran berpikir bersama merupakan jenis pembelajaran kooperatif yang dirancang untuk mempengaruhi pola interaksi siswa dan sebagai alternatif terhadap struktur kelas tradisional. Dalam pembelajaran ini siswa dibagi dalam kelompok yang beranggotakan 3-5 orang dan setiap anggota kelompok diberi nomor 1-5, kemudian guru PJOK mengajukan pertanyaan kepada siswa yang nantinya siswa berpikir bersama untuk menyatukan pendapat terhadap jawaban atas pertanyaan yang diberikan dan meyakinkan tiap anggota kelompoknya untuk mengetahui jawaban itu, setelah itu guru PJOK memanggil satu nomor tertentu, kemudian siswa yang nomornya sesuai mengancungkan tangannya dan mencoba untuk menjawab pertanyaan untuk seluruh kelas. Kelebihan model pembelajaran kooperatif tipe NHT yaitu: (1) Terjadinya interaksi antara siswa melalui diskusi/siswa secara bersama dalam menyelesaikan masalah yang dihadapi, (2) Siswa pandai maupun siswa lemah sama-sama memperoleh manfaat melalui aktifitas belajar kooperatif, (3) Dengan bekerja secara kooperatif ini, kemungkinan konstruksi pengetahuan akan manjadi lebih besar/kemungkinan untuk siswa dapat sampai pada kesimpulan yang diharapkan, (4) Dapat memberikan kesempatan kepada siswa untuk menggunakan keterampilan bertanya, berdiskusi, dan mengembangkan bakat kepemimpinan.

Guru berperan sebagai fasilitator yaitu akan berpartisipasi aktif dalam memberikan bimbingan bagi siswa untuk menemukan dan membantu memecahkan kesulitan belajarnya, bukan sebagai sumber pemecahannya. Selain itu, adanya tanggung jawab perorangan dalam model pembelajaran ini dapat memberikan motivasi dan kepercayaan dalam belajar dimana siswa diharapkan mampu bekerja mandiri. 
Berdasarkan hasil data nilai ulangan harian pada materi bola besar khususnya pada permainan bola voli teknik dasar passing bawah dan passing atas pada siswa kelas XI MIA SMA Saraswati Seririt ditemukan bahwa pada kelas XI MIA, siswa yang tuntas berjumlah 11 orang dan siswa yang tidak tuntas berjumlah 26 orang dengan rincian 26 orang memperoleh nilai $<70,4$ orang memperoleh nilai 70,7 orang memperoleh nilai $71-75$, dan tidak ada yang memperoleh nilai $>75$. Pada kelas XI IIS 1 , siswa yang tuntas berjumlah 7 orang dan siswa yang tidak tuntas berjumlah 29 orang dengan rincian 29 orang memperoleh nilai < 70,2 orang memperoleh nilai 70,5 orang memperoleh nilai $71-75$, dan tidak ada yang memperoleh nilai $>75$. Pada kelas XI IIS 2, siswa yang tuntas berjumlah 10 orang dan siswa yang tidak tuntas berjumlah 26 orang dengan rincian 26 orang memperoleh nilai < 70,5 orang memperoleh nilai 70,5 orang memperoleh nilai 71-75, dan tidak ada yang memperoleh nilai $>75$. Pada kelas XI IIS 3 siswa yang tuntas berjumlah 13 orang dan siswa yang tidak tuntas berjumlah 23 orang dengan rincian 23 orang memperoleh nilai < 70,7 orang memperoleh nilai 70,6 orang memperoleh nilai $71-75$, dan tidak ada yang memperoleh nilai $>75$. Pada kelas XI IIS 4 siswa yang tuntas berjumlah 15 orang dan siswa yang tidak tuntas berjumlah 21 orang dengan rincian 21 orang memperoleh nilai < 70 , 8 orang memperoleh nilai 70,7 orang memperoleh nilai $71-75$, dan tidak ada yang memperoleh nilai $>75$. Berdasarkan hasil data di atas bahwa, masih banyak terdapat nilai siswa yang belum mencapai nilai ketuntasan minimal (KKM). Permasalahan siswa muncul dikarenakan guru yang menggunakan model pembelajaran yang masih konvensional yang membuat siswa tidak aktif dan mengakibatkan siswa tidak serius mengikuti pembelajaran, ini ditandai dengan sikap kurang antusiasnya siswa dalam menerima pelajaran PJOK khususnya pada materi teknik dasar passing bawah dan passing atas bola voli. Sarana dan prasarana juga di SMA Saraswati Seririt ini masih kurang memadai.
Oleh sebab itu adanya upaya peneliti guna meningkatkan hasil belajar siswa dengan solusi menerapkan model pembelajaran yang inovatif dan dapat mengacu semangat pada siswa di dalam mengikuti pembelajaran. Salah satu model pembelajaran yang dimaksud oleh peneliti adalah model pembelajaran kooperatif tipe Numbered Head Together. Pemilihan tentang model pembelajaran kooperatif tipe NHT ini juga dikuatkan oleh hasil penelitian dari peneliti-peneliti sebelumnya, diantaranya: (1) Sabrina (2014) yang menemukan bahwa ada pengaruh yang signifikan model pembelajaran kooperatif tipe Numbered Head Together (NHT) terhadap hasil belajar passing bawah bola voli pada siswa kelas XI TPM 1 SMK PGRI 2 Kota Pasuruan yang dibuktikan dari nilai thitung $(15,8666)>$ ttabel $(2,032)$ dengan taraf signifikan 0,05 .Sedangkan besar pengaruhnya diketahui sebesar 21,38\%. (2) Rohmawati (2012) juga menemukan bahwa model pembelajaran kooperatif tipe NHT berpengaruh terhadap peningkatan hasil belajar matematika siswa kelas V SD Negeri Keceme 1 Kecamatan Sleman. Hal tersebut dibuktikan dengan hasil thitung lebih besar ttabel yaitu sebesar 2,135 > 2,002. (3) Fajrin (2014) penggunaan model pembelajaran kooperatif tipe Numbered Head Together (NHT) berpengaruh terhadap hasil belajar dribbling sepak bola pada siswa kelas XISMA Negeri 1 Tarik Sidoarjo dengan hasil t hitung 18.58 > t tabel 1.69. (4) SuryaJaya (2017) penerapan model pembelajaran kooperatif tipe NHT berpengaruh sangat signifikan terhadap hasil belajar materi teknik dasar passing bawah control sepak bola kaki bagian dalam pada siswa kelas XITKJ SMK Negeri 3 Singaraja, uji normalitas sebaran data dengan menggunakan teknik Kolmogorov-Smirnov, didapatkan signifikansi kelompok eksperimen 0,200>0,05.

Berdasarkan apa yang telah diungkapkan tersebut di atas maka peneliti tertarik untuk mengangkat judul penelitian "Pengaruh Model Pembelajaran Kooperatif Tipe Numbered Head Together (NHT) Terhadap Hasil Belajar Passing Bola Voli 
Pada Siswa Kelas XI SMA Saraswati Seririt Tahun Pelajaran 2019/2020".

Tujuan dalam penelitian ini adalah untuk mengetahui pengaruh model pembelajaran NHT terhadap hasil belajar teknik dasar passing bola voli pada siswa kelas XI SMA Saraswati Seririt tahun pelajaran 2019/2020.

\section{KAJIAN TEORI Hasil Belajar Passing}

Menurut Suprijono (2009:7) Hasil belajar merupakan perubahan perilaku secara keseluruhan bukan hanya salah satu aspek potensi kemanusiaan, artinya hasil pembelajaran tersebut tidak dilihat secara fragmentaris atau terpisah melainkan komprehensif. Hasil belajar adalah suatu pencapaian tujuan pendidikan pada siswa setelah mengikuti proses belajar mengajar.

Permainan bola voli merupakan suatu permainan yang kompleks yang tidak mudah untuk dilakukan Ahmadi,N (2007:20). Dibutuhkan koordinasi gerak yang benarbenar bisa diandalkan untuk melakukan semua gerakan yang ada dalam permainan bola voli. Teknik dasar dalam permainan bola voli menurut Budhiarta, Danu (2008:28) adalah sebagai berikut. 1) Sikap penjagaan dan cara penggerakan, 2) Passing dan umpan, 3) Serangan (Spike-serangan tipuan), 4) Bendungan/blok, 5) Servis.

Jadi, hasil belajar passing bola voli adalah perubahan perilaku yang mencakup aspek kognitif dan psikomotor setelah melakukan proses belajar passing yang meliputi sikap awal, pelaksanaan dan sikap akhir gerakan.

\section{Model Pembelajaran}

Menurut Joyce (dalam Trianto, 2007:

5) model pembelajaran adalah, "Suatu perencanaan atau suatu pola yang digunakan sebagai pedoman dalam merencanakan pembelajaran di kelas untuk menentukan perangkat-perangkat pembelajaran termasuk di dalamnya bukubuku, film, komputer, kurikulum, dan lainlain."

\begin{abstract}
Model Pembelajaran Kooperatif nerupakan pembelajaran yang lebih menekankan pada aspek kerjasama siswa dalam kelompok, yaitu saling membantu dalam menyelesaikan masalah yang dihadapi. Terdapat 4 (empat) metode pembelajaran kooperatif yang biasa
\end{abstract} digunakan oleh guru yaitu : 1. Tipe Student Teams Achievement Divisions (STAD), 2. Tipe Jigsaw, 3. Tipe Group Investigations (GI), 4. Tipe Struktural.

Numbered Head Together (NHT) atau penomoran berpikir bersama adalah merupakan jenis pembelajaran kooperatif yang dirancang untuk mempengaruhi pola interaksi siswa dan sebagai altenatif terhadap struktur kelas tradisional. Dalam mengajukan pertanyaan kepada seluruh kelas, guru menggunakan struktur empat fase sebagai sintaks NHT yaitu: 1. Penomoran, 2. Mengajukan Pertanyaan, 3. Berfikir Bersama, 4. Menjawab.

Pembelajaran

konvensional merupakan pembelajaran yang sudah biasa digunakan oleh guru dimana pembelajaran ini menekankan pada guru sebagai pusat informasi dan siswa sebagai penerima informasi. Situasi kelas sebagian besar masih berfokus pada guru sebagai sumber utama pengetahuan, serta pengguanaan metode ceramah sebagai pilihan utama strategi belajar mengajar. Ceramah adalah, "Sebuah bentuk interaksi melalui penerangan dan penuturan lisan dari guru ke peserta didik" (Sagala, 2010: 201). "Metode ceramah mempunyai kelemahan dipandang dari segi kepentingan belajar murid-murid, seperti: (1) Guru sukar mengetahui sampai dimana murid-murid telah mengerti pembicaraannya, (2) Murid sering memberikan pengertian lain dari hal yang dimaksudkan guru." (Suryosubroto, 2009: 156).

\section{METODE}

Jenis penelitian yang digunakan dalam penelitian ini adalah eksperimen sungguhan (true experimental). Rancangan pada penelitian ini adalah rancangan the randomized pretest- posttest control group 
the same subject design (yang ditampilkan pada gambar berikut).

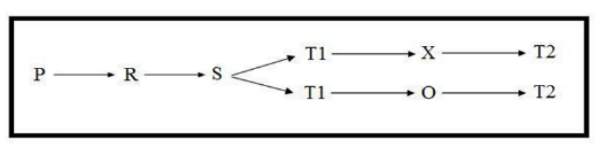

Gambar 3.1

Rancangan Penelitian (Kanca, 2010:87)

Keterangan:

$\mathrm{P} \quad=\quad$ Populasi

$\mathrm{R}=$ Random

$\mathrm{S}=$ Sampel

$\mathrm{T} 1=$ Tes Awal (pretest)

$\mathrm{T} 2=$ Tes Akhir (posttest)

$\mathrm{X}=$ Kelompok Eksperimen

$\mathrm{O}=$ Kelompok Kontrol

Populasi dalam penelitian ini yaitu siswa kelas XI SMA Saraswati Seririt tahun pelajaran 2019/2020. Dalam penentuan sampel peneliti menggunakan teknik simple random sampling. Yang menjadi sampel dalam penelitian ini yaitu kelas XI Sma Saraswati Seririt.
Prosedur pengumpulan data dilakukan dengan memberikan pretest dan posttest perlakuan.

Jenis instrumen yang digunakan adalah asesmen teknik dasar passing bola voli . Data tentang hasil belajar siswa dilakukan dengan menggunakan instrumen berupa asesmen hasil belajar teknik dasar passing bola voli.

Sebelum dilakukan pengujian untuk mendapatkan simpulan, data yang diperoleh perlu diuji normalitas dan homogenitasnya setelah itu dilanjutkan: Analisis data pada penelitian ini akan menggunakan bantuan program SPSS 16.0 for Windows.

\section{HASIL DAN PEMBAHASAN Hasil Penelitian}

Rangkuman analisis terhadap data hasil belajar teknik dasar passing bola voli pada kelompok eksperimen dan kelompok kontrol seperti tercantum pada Tabel 01.

Tabel 01

Rangkuman Data Hasil Belajar Teknik Dasar Passing Bola Voli

\begin{tabular}{lccc}
\hline \multicolumn{1}{c}{ Descriptive Statistics } \\
\hline Variabel & $\begin{array}{c}\text { Banyak Peserta } \\
\text { didik }\end{array}$ & Rata-Rata & Std. Deviation \\
\hline $\begin{array}{l}\text { Kelas Kelompok } \\
\text { Ekperimen }\end{array}$ & 36 & 0,70 & 0,14 \\
\hline Kelas Kelompok Kontrol & 36 & 0,62 & 0,135 \\
\hline
\end{tabular}

Berdasarkan Tabel 01 tentang hasil pretest dan posttest di kedua kelompok sampel diperoleh rata-rata skor kelompok eksperimen adalah 0,70 sedangkan rata-rata skor kelompok control adalah 0,62. Standar deviasi dari kelompok eksperimen yaitu 0,14 sedangkan standar deviasi dari kelompok kontrol yaitu 0,135 .

Sebelum uji hipotesis dilakukan, terlebih dahulu dilakukan pengujian prasyarat terhadap sebaran data yang meliputi uji normalitas sebaran data dan uji homogenitas varians. Berikut ini diuraikan mengenai hasil pengujian normalitas sebaran data dan homogenitas varian terhadap hasil belajar teknik dasar passing bola voli.

Pengujian normalitas sebaran data dilakukan untuk meyakinkan bahwa subjek penelitian berdistribusi normal yang tercantum pada tabel 02. 
Tabel 02

Hasil Uji Normalitas sebaran Data

\begin{tabular}{|c|c|c|c|c|c|c|c|}
\hline & KELAS & Statistic & Df & Sig. & Statistic & & Sig. \\
\hline \multirow[t]{2}{*}{ Gainscor } & EKSPERIMEN & .145 & 36 & .055 & .895 & 36 & .033 \\
\hline & KONTROL & .142 & 36 & .036 & .900 & 36 & .033 \\
\hline
\end{tabular}

Uji normalitas yang digunakan adalah Uji Kolmogorov-Smirnov. Jika nilai sig pada kolom Kolmogorov-Smirnov untuk kedua kelas lebih dari 0.05 maka data kedua kelas berasal dari populasi yang berdistribusi normal. Nilai sig untuk kelas XI IIS 4 dan kelas XI MIA adalah 0.055 dan 0.066 yaitu lebih dari 0.05 sehingga data kedua kelas berasal dari populasi yang berdistribusi normal. 0,05 maka dengan demikian semua sebaran data berdistribusi normal.

Uji homogenitas varian dilakukan dengan pengelompokan berdasarkan model pembelajaran, yaitu model pembelajaran kooperatif tipe NHT dengan model pembelajaran konvensional. Uji homogenitas varians antar kelompok dilakukan dengan bantuan SPSS 16.00 for Windows dengan

\section{Tabel 4.3}

menggunakan Levene's Test Of Equality Error Variance. Hipotesis statistik yang diuji dalam pengujian homogenitas adalah sebagai berikut:

$\begin{array}{lll}H_{0} & : \quad \text { variansi pada setiap } \\ & \begin{array}{l}\text { kelompok adalah sama } \\ \text { (homogen) }\end{array} \\ H_{a} \quad \text { variansi pada setiap } \\ \\ \begin{array}{l}\text { kelompok tidak sama } \\ \text { homogen) }\end{array}\end{array}$

Dengan kriteria pengujian yang digunakan adalah terima $H_{0}$ jika nilai $p>0,05$ dimana data memiliki varians yang sama apabila angka signifikansi yang dihasilkan lebih dari 0,05. Rangkuman hasil perhitungan homogenitas data menggunakan SPSS 16.00 for Windows dapat dilihat pada Tabel 03.

Rangkuman Hasil Uji Homogenitas Varian

\begin{tabular}{cccc}
\hline Levene Statistic & $\mathrm{df1}$ & $\mathrm{df2}$ & Sig. \\
\hline .027 & 1 & 70 & .871 \\
\hline
\end{tabular}

Berdasarkan Tabel 03, hasil uji Levene's Test of Equality of Error Variances menunjukkan bahwa untuk hasil belajar teknik dasar passing bola voli siswa bertaraf signifikan 0,871. Bila ditetapkan taraf signifikansi 0,05 maka nilai sig lebih besar dari taraf signifikansi yang ditetapkan. Dengan demikian hipotesis nol diterima. Artinya, semua kelompok data memiliki varians yang sama (homogen). 
Berdasarkan uji prasyarat analisis data, diperoleh bahwa data pretest dan posttest kelompok eksperimen dan kelompok kontrol adalah normal dan homogen. Setelah diperoleh hasil uji prasyarat analisis data, dilanjutkan dengan pengujian hipotesis penelitian $\left(\mathrm{H}_{\mathrm{a}}\right)$ dan hipotesis nol $\left(\mathrm{H}_{0}\right)$. Pengujian hipotesis tersebut dilakukan dengan menggunakan Independent Samples Test bantuan SPSS 16.00 for Windows Uji Hipotesis.

Tabel 04

Ringkasan Analisis Uji-t Dengan Menggunakan SPSS 16.00 for Windows

Levene's Test for

Equality of

Variances t-test for Equality of Means
95\% Confidence

Interval of the

Difference

\begin{tabular}{|c|c|c|c|c|c|c|c|c|c|c|}
\hline & & $\mathrm{F}$ & Sig. & $\mathrm{T}$ & Df & $\begin{array}{l}\text { Sig. (2- } \\
\text { tailed) }\end{array}$ & $\begin{array}{c}\text { Mean } \\
\text { Difference }\end{array}$ & $\begin{array}{l}\text { Std. Error } \\
\text { Difference }\end{array}$ & Lower & Upper \\
\hline \multirow[t]{2}{*}{ NILAI } & $\begin{array}{l}\text { Equal variances } \\
\text { assumed }\end{array}$ & .027 & .871 & 2.397 & 70 & .019 & .07778 & .03244 & .01307 & .14248 \\
\hline & $\begin{array}{l}\text { Equal variances } \\
\text { not assumed }\end{array}$ & & & 2.397 & 69.887 & .019 & .07778 & .03244 & .01307 & .14248 \\
\hline
\end{tabular}

Berdasarkan Tabel 4.4, pada kolom sig (2-tailed) jika nilai sig $<0.05$ artinya $\mathrm{H}_{\circ}$ ditolak dan $\mathrm{H}_{a}$ diterima. Nilai sig untuk uji hipotesis adalah $0.019<0.05(\mathrm{P}<0.05)$ sehingga $\mathrm{H}_{\mathrm{o}}$ ditolak dan $\mathrm{H}_{\mathrm{a}}$ diterima. Hasil ini menyatakan bahwa terdapat perbedaan hasil belajar teknik dasar passing bola voli antara siswa yang diberi perlakuan dengan model pembelajaran kooperatif tipe NHT dengan siswa yang diberi perlakuan dengan model pembelajaran konvensional. Sehingga model pembelajaran kooperatif tipe NHT berpengaruh signifikan terhadap hasil belajar teknik dasar passing bola voli pada siswa kelas XI SMA Saraswati Seririt.

\section{PEMBAHASAN HASIL PENELITI}

Berdasarkan hasil analisis data menggunakan program SPSS 16.0 for
Windows, diperoleh bahwa terdapat perbedaan hasil belajar teknik dasar passing bola voli antara kelompok eksperimen yang diberikan perlakuan menggunakan model pembelajaran kooperatif tipe NHT dengan kelompok kontrol yang diberikan perlakuan menggunakan model pembelajaran konvensional.

NHT adalah salah satu tipe pembelajaran kooperatif yang menempatkan siswa dalam kelompok-kelompok belajar yang beranggotakan 5-6 orang yang memiliki kemampuan, jenis kelamin dan suku kata atau ras yang berbeda. Guru menyajikan materi, dan siswa bekerja serta bertanggung jawab dalam kelompok mereka masingmasing. Apabila ada dari anggota kelompok yang tidak mengerti dengan tugas yang diberikan, maka anggota kelompok yang lain 
bertanggung jawab untuk memberikan jawaban atau menjelaskannya, sebelum mengajukan pertanyaan tersebut kepada guru.

Berdasarkan pengamatan peneliti pada saat pembelajaran berlangsung di kelompok eksperimen, pembelajaran diarahkan untuk memberikan perhatian terhadap pemahaman siswa tentang teknik dasar passing bola voli di dalam mengikuti pelajaran. Aktivitas siswa yang lebih positif dalam menelaah materi suatu pelajaran pada kegiatan belajar menjadi salah satu faktor yang membuat rata-rata skor yang diperoleh siswa pada kelompok eksperimen lebih besar dari pada rata-rata skor yang diperoleh siswa pada kelompok kontrol. Hal ini sejalan dengan pernyataan Trianto (2007: 82) yang menyatakan NHT dirancang untuk melibatkan lebih banyak siswa dalam menelaah materi yang tercakup dalam suatu pelajaran dan mengecek pemahaman mereka terhadap isi pelajaran tersebut. Model pembelajaran kooperatif tipe NHT dirancang untuk mempengaruhi pola interaksi siswa dan alternatif terhadap struktur kelas tradisional.Pembelajaran yang dilaksanakan di kelompok kontrol dilaksanakan dengan menerapkan model pembelajaran konvensional. Pembelajaran dikelompok kontrol dilakukan oleh guru PJOK dalam penyampaian materi kemudian mendemonstrasikan materi pelajaran dan menugaskan siswa untuk mempraktikkan materi yang diajarkan. Melalui penugasan tersebut diharapkan siswa mampu memahami dan melakukan gerakan dengan benar

Berdasarkan pengamatan peneliti pada saat pembelajaran berlangsung, model konvensional yang diterapkan di kelompok kontrol pada dasarnya telah menuntun siswa untuk dapat memahami dan mempraktikan gerakan dengan benar. Namun dalam penyampaian materi pembelajarannya menyebabkan pembelajaran berpusat pada guru dan masih banyak siswa yang kurang aktif. Hal ini mengakibatkan kurangnya partisipasi siswa secara menyeluruh dalam proses belajar mengajar atau hanya siswa yang memiliki kemampuan lebih saja yang mau aktif dalam proses pembelajaran, sehingga pemahaman dan keterampilan siswa dalam melakukan teknik dasar passing bola voli menjadi terhambat dan tidak merata.

Sedangkan hal ini berbeda dengan pembelajaran pada kelompok eksperimen dengan menggunakan model pembelajaran kooperatif tipe NHT dimana siswa yang dibelajarkan melalui kelompok-kelompok kecil yang setiap anggota di dalam kelompoknya diberikan nomor per kepala yang akan digunakan guru menunjuk salah satu siswa pada masing-masing kelompok untuk menjelaskan hasil diskusi kelompoknya. Hal tersebut dapat memberikan tanggung jawab pada seluruh anggota kelompok untuk memahami materi yang diajarkan sehingga akan melibatkan partisipasi seluruh siswa. Faktor-faktor tersebutlah yang mengakibatkan pembelajaran yang berlangsung di kelompok eksperimen mendapat respon yang lebih baik dari siswa sehingga rata-rata skor siswa di kelompok eksperimen lebih tinggi daripada rata-rata skor siswa pada kelompok kontrol.

\section{SIMPULAN DAN SARAN}

Berdasarkan rumusan masalah, tujuan penelitian, hipotesis penelitian, analisis data dan pembahasan yang dipaparkan pada bab terdahulu, maka kesimpulan peneliti adalah terdapat hubungan yang signifikan antara model pembelajaran yang diterapkan dalam pembelajaran terhadap hasil belajar siswa. Penerapan model pembelajaran kooperatif tipe NHT berpengaruh signifikan terhadap peningkatan hasil belajar teknik dasar passing bola voli pada siswa kelas XI SMA Saraswati Seririt tahun pelajaran 2019/2020.

Adapun saran yang dapat diajukan berdasarkan analisis dan pembahasan diatas agar nantinya dapat digunakan dalam proses pembelajaran dan penelitian kedepannya yaitu sebagai berikut.

Pertama, bagi guru PJOK model pembelajaran kooperatif tipe NHT dapat dijadikan salah satu alternatif pembelajaran yang dapat diterapkan di kelas. 
Kedua, penelitian ini dilaksanakan pada pokok bahasan teknik dasar passing bola voli di kelas XI SMA Saraswati Seririt, sehingga untuk memperoleh bukti-bukti yang lebih umum dari penerapan model pembelajaran kooperatif tipe NHT diharapkan peneliti lain untuk mencoba pada pokok bahasan lain untuk mengetahui pengaruh penerapan model pembelajaran kooperatif tipe NHT dalam pembelajaran PJOK secara lebih mendalam

Dan ketiga, penelitian ini hanya mengukur ada atau tidaknya pengaruh dari model pembelajaran kooperatif tipe NHT terhadap hasil belajar teknik dasar passing bola voli tanpa meneliti lebih jauh arah pengaruh yang diberikan. Di waktu mendatang dapat dilakukan suatu penelitian untuk meneliti sejauh mana arah pengaruh yang diberikan oleh model pembelajaran kooperatif tipe NHT terhadap hasil belajar PJOK siswa.

\section{DAFTAR RUJUKAN}

Ahmadi, N. 2007. Panduan Olahraga Bola Voli. Surakarta: Era Pustaka Utama

Caka,puja.2017. Pengaruh Model Pembelajaran Kooperatif tipe NHT Terhadap Hasil Belajar Teknik Dasar Passing Bola Voli Pada Siswa Kelas X SMK Negeri 3 Singaraja Tahun Pelajaran 2016/2017.Singaraja: Undiksha.

Dantes, Nyoman. 2012. Metode Penelitian. Yogyakarta: ANDI

Danu Budhiarta, I Made. 2008. Teori Praktik Permainan Bola Voli dan Bola Voli Pantai. Singaraja : Universitas Pendidikan Ganesha.

Dimyati dan Mudjiono. 2006. Belajar dan Pembelajaran. Departemen Pendidikan Nasional

Fajrin, Yanuar N. 2014. "Pengaruh Penerapan Model Pembelajaran Kooperatif Tipe Numbered Head Together (NHT) Terhadap Hasil
Belajar Dribbling Sepakbola (Studi Pada Siswa Kelas XISMA Negeri 1 Tarik Sidoarjo)". Tersedia pada

http://ejournal.unesa.ac.id/indeXI.php/i urnal-pendidikan-

jasmani/article/view/9967 Vol 2, No 2 (diakses pada tanggal 21Desember 2016).

Kanca, I Nyoman. 2010. Metode Penelitian Pengajaran Pendidikan Jasmani dan Olahraga. Singaraja : Universitas Pendidikan Ganesha.

Ma'mun, Amung \& Toto Subroto. 2001. Pendekatan Keterampilan Taktis dalam Permainan Bola Voli. Jakarta Pusat: Direktorat Jenderal Olahraga

Nurhadi dkk, 2004. Pembelajaran Kontekstual dan Penerapannya dalam KBK. Malang: Universitas Negeri Malang.

Permendikbud. 2016. Standar Proses Pendidikan Dasar Dan Menengah. Jakarta : Badan Standar Nasional Pendidikan.

Pratama Sari, Sabrina. 2014. "pengaruh model pembelajaran kooperatif tipe numbered head together (NHT) terhadap hasil belajar passing bawahbawah bolavoli (studi pada siswa kelas XI tpm 1 smk pgri 2 kota pasuruan)".

Tersediapadahttps://scholar.google.co . id/scholar? $\mathrm{q}=$ pengaruh + model+pemb elajaran+kooperatif+tife+nht+terhadap +hasil+belajar+passing+atas+bola+vo li\&btnG=\&hl=id\&as sdt=0\%2C5 (diakses pada 11 Nopember 2016).

Purwanto, 2009. Evaluasi Hasil Belajar. Yogyakart a: Pustaka Pelajar.

Rohmawati. 2012. Model pembelajaran kooperatif tipe NHT berpengaruh terhadap peningkatan hasil belajar matematika siswa kelas V SD Negeri 1 Kecamatan Sleman. Tersedia pada http://ejournal.unesa.ac.id/indeXI.php/i 
urnal-pendidikan

jasmani/article/view/9967 Vol 2, No 2 (diakses pada tanggal 21 Desember 2016).

Rusman. 2013. Model-model Pembelajaran. Jakarta: PT RajaGrafindo Persada.

Sagala, Syaiful. 2010. Konsep dan Makna Pembelajaran. Bandung: Alfabeta

Sudjana, Nana. 2009. Penilaian Hasil Proses Belajar Mengajar. Bandung: PT Remaja Rosdakarya.

Sugiyono. 2012. Metode Penelitian Pendidikan Pendekatan Kuantitatif, Kualitatif, dan R\&D. Bandung: Alfabeta.

Suprijono, A. 2009. Cooperative Learning: Teori dan Aplikasi PAIKEM. Yogyakarta: Pustaka Belajar.

Suryajaya, 2017. Pengaruh Model Pembelajaran Kooperatif Tipe Numbered Head Together (NHT) Terhadap Hasil Belajar Passing bawahControl Sepak Bola Tersedia pada

https://ejournal.undiksha.ac.id/indeXI. php/JJP/article/download/11281/7206

Suryosubroto, B. 2009. Proses Belajar Mengajar di Sekolah. Jakarta: PT Rineka Cipta.

Trianto, 2007. Model- Model Pembelajaran Inovatif Berorientasi

Konstruktif.Jakarta :Prestasi Pustaka

Wijaya,agus.2015.Developing Fundamental Movement Based Cooperative J

Learning Model in Primary School.Singaraja: Google Scholar. 